\title{
Kandungan Alkalloid dan Steroid Pada Tanaman Kolesom ( Talinumtriangulare (Jacq. )Willd.) Akibat Perbedaan Daerah Asal Tanaman
}

\author{
Alkaloids and Steroids Contain of Kolesom (Talinum Triangulare (Jacq.) Willd.) \\ due to Differences in the Origin of Plants
}

\author{
Mariya Ulfa $^{1}$, Suhartono ${ }^{1}$, Eko Setiawan ${ }^{1}$ \\ ${ }^{1}$ Program Studi Agroteknologi, Fakultas Pertanian, Universitas Trunojoyo Madura \\ Jl. Raya Telang PO BOX 2 Kamal Bangkalan Madura, Indonesia, 69162 \\ E-mail: hartono_unijoyo@yahoo.co.id
}

Diterima 19 Februari 2017/Disetujui 27 Maret 2017

\begin{abstract}
Ginseng is one of a family of plants sekulen portulaceae are medicinal. Medicinal plants in Indonesia is growing more rapidly, in line with the increasing public awareness of the re-use of materials of natural medicine. Natural ingredients is safe to eat and coined the lower side effects compared with synthetic drugs made from chemicals. This research aims to know the effect of differences in the area of origin of the seeds and steroid alkaloid content in the ginseng plant. This research was conducted at the University of Tronojoyo Bangkalan, Madura. The experiments were performed in a non factorial completely randomized design (CRD). These factors are: A1: Originally plants Kangean Islands, A2 : Originally plants Bangkalan, A3 : Origin Lumajang plants that will be tested with alkaloids and steroids. The results showed no effect of ginseng plant seed origin on the content of alkaloids and steroids on plant height.
\end{abstract}

Keywords: Plants Kolesom, Alkaloids, Steroids

\begin{abstract}
ABSTRAK
Kolesom merupakan salah satu tumbuhan sekulen dari famili portulaceae yang berkhasiat obat. Tanaman obat di Indonesia berkembang semakin pesat, sejalan dengan meningkatnya kesadaran masyarakat akan kembali menggunakan bahan-bahan obat alami. Bahan obat alami lebih aman dikonsumsi dan memiiki efek samping yang lebih rendah dibandingkan dengan obat-obat sintetik yang terbuat dari bahan kimia. Penelitian ini bertujuan untuk Mengetahui pengaruh perbedaan daerah asal bibit terhadap kandungan alkaloid dan steroid pada tanaman kolesom. Penelitian ini dilakukan di Universitas Tronojoyo Bangkalan, Madura. Percobaan dilakukan secara non faktorial dengan Rancangan AcakLengkap (RAL). Faktor tersebut yaitu: A1 : Asal tanaman Kepulauan Kangean, A2 : Asal tanaman Kabupaten Bangkalan, A3 : Asal tanaman Kabupaten Lumajang yang akan diujikan dengan alkaloid dan steroid. Hasil penelitian menunjukkan ada pengaruh asal bibit tanaman kolesom terhadap kandungan alkaloid dan steroid pada daun dan umbi.
\end{abstract}

Kata kunci: Tanaman Kolesom, Alkaloid, Steroid.

\section{PENDAHULUAN}

Tanaman obat di Indonesiaberkembang semakin pesat, sejalan dengan meningkatnya kesadaran masyarakat akan kembali menggunakan bahan-bahan obat alami. Bahan obat alami lebih aman dikonsumsi dan memiliki efek samping yang lebih rendah dibandingan dengan obat-obat sintetik yang terbuat dari bahan kimia. Sehingga terkenal di semua kalangan masyarakat sebagai pilihan kebutuhan dalam pengobatan.

Kolesom merupakan salah satu tumbuhan sekulen dari famili portulaceae yang berkhasiat obat (Susanti et al., 2008). Kolesom banyak ditemukan sebagai gulma di daerah tropika atau dibudidayakan sebagai tanaman sayuran dan obat. Bagian tanaman kolesom yang berkhasiat obat adalah daun, batang, akar, dan umbi atau seluruh bagian tanaman (Mualim et al., 2009). Selain itu, kolesom juga banyak berkembang di daerah kepulauan dan kota. Namun sebagian besar masyarakat masih belum menyadari pentingnya kandungan kolesom sebagai tanaman obat.

Kandungan bahan bioaktif daun dan umbi tanaman kolesom pada berbagai dosis pupuk kandang ayam yaitu antaranya alkaloid, steroid, saponin, dan tanin. Alkaloid merupakan suatu golongan senyawa organik yang terbanyak ditemukan di alam. Hampir seluruh alkaloid berasal dari tumbuh-tumbuhan dan tersebar luas dalam berbagai jenis tumbuhan tingkat tinggi. Sebagian besar alkaloid terdapat pada tumbuhan dikotil sedangkan untuk tumbuhan monokotil dan pteridofita mengandung alkaloid dengan kadar yang sedikit.Sedangkan steroid merupakan senyawa 
yang memiliki kerangka dasar triterpena asiklik(Wijayakusuma, 1996).

Metabolit sekunder merupakan senyawa metabolit yang tidak esensial bagi pertumbuhan organisme dan ditemukan dalam bentuk yang unik atau berbeda-beda antara spesies yang satu dan lainnya. Metabolit sekunder adalah berbagai macam reaksi yang produknya tidak secara langsung terlibat dalam pertumbuhan normal. Dalam hal ini metabolit sekunder berbeda dengan bahan metabolit intermediet yang memang merupakan produk dari metabolisme normal (Santoso, 2003).Melihat kandungan metabolit sekunder dari tanaman kolesom yang sangat bermanfaat sebagai tanaman obat, sehingga dilakukan penelitian terkait dengan kandungan metabolit sekunder pada tanaman kolesom dengan asal stek yang berbeda lokasi agar dapat diketahui kandungan metabolit sekunder khususnya alkaloid dan steroid yang baik. Serta mampu menghasilkan pertumbuhan produksi stek kolesom yang berkualitas dengan potensi daerah yang berbeda untuk dijadikan sebagai tanaman penghasil bibit.

Tanaman kolesom yang digunakan untuk penelitian adalah kolesom yang berasal dari Kangean, Bangkalan dan Lumajang. Alasan memilih ketiga daerah ini karna diharapkan masyarakat masih memanfaatkan tanaman kolesom sebagai tanaman obat, sehingga saya ingin mengetahui dari ketiga daerah tersebut, tanaman kolesom yang baik dan layak untuk dijadikan obat dan mempunyai kandungan yang tertinggi pada perlakuan yang mana. Tanaman kolesom di manfaatkan karna kandungannya, salah satunya steroid dan alkaloid, dimana alkaloid terdapat pada tumbuhan dikotil sedangkan steroid senyawa yang memiliki kerangka dasar triterpena asiklik.

Tujuan penelitian ini untuk mengetahui pengaruh perbedaan daerah asal tanaman terhadap pertumbuhan dan hasil serta kandungan alkaloid dan steroid pada tanaman kolesom.

\section{BAHAN DAN METODE}

Penelitian ini dilaksanakan di kebun percobaan Universitas Trunojoyo Madura, Kecamatan Kamal, Kabupaten Bangkalan Madura.Penelitian berlangsung mulai bulan Juni sampai Agustus 2014.

Bahan tanam yang digunakan adalah tanaman kolesom yang berasal dari daerah berbeda diantaranya, Kepulauan Kangean, Kabupaten Bangkalan, dan Kabupaten Lumajang. Pengambilan stek pada tanaman yang meliputi stek pucuk.
Pengamatan dilakukan setelah tananam berumur 1 sampai 8 minggu setelah tanam (MST). Pengamatan dilakukan 1 minggu sekali.

Variabel yang diamati antara lain:
a. Tinggi tanaman
b. Jumlah daun
c. Jumlah cabang
d. Bobot basah tanaman $(\mathrm{g})$
e. Bobot kering tanaman $(\mathrm{g})$
f. Kandungan Alkaloid
g. Kandungan Steroid

Penelitian ini menggunakan Rancangan Acak Lengkap (RAL) non Faktorial dengan 5 kali ulangan. Perlakuan yang dicoba yaitu perbedaan daerah asal bibit terhadap kandungan alkaloid dan steroid pada tanaman kolesom. Faktor tersebut yaitu:

A1: Asal tanaman Kepulauan Kangean.

A2: Asal tanaman Kabupaten Bangkalan.

A3: Asal tanamanKabupaten Lumajang.

Analisis data diolah menggunakan Analisis Of Varians (ANOVA) dan apabila terdapat pengaruh perlakuan yang nyata maka dilanjutkan dengan Uji Jarak Duncan (UJD) dengan taraf $5 \%$.

\section{HASIL DAN PEMBAHASAN}

\section{Hasil}

Pada Tabel 1. Karakteristik bahan tanan dari beberapa perlakuan yaitu diantaranya Kepulauan Kangean, Kabupaten Bangkalan, Kabupaten Lumajang mempunyai karakteristik yang berbeda - beda. Pada Kepulauan Kangean bentuk batangnya bulat, warna daunnya coklat muda, diameter batang lebar $(\mathrm{cm})$, daunnya tidak terlalu tebal. Pada Kabupaten Bangkalan, bentuk batangnya lurus, warnanya coklat muda, diameter batang kecil (cm), daunnya tebal. Sedangkan Kabupaten Lumajang bentuk batang lurus, warnanya kecoklatan, diameter kecil $(\mathrm{cm})$, daunnya tipis.

\section{Tinggi tanaman}

Hasil analisis sidikragam tinggi tanaman menunjukkan bahwa perbedaan asal bibit tanaman kolesom tidak memberikan pengaruh nyata terhadap tinggi tanaman pada umur tanaman 2,3,4,5,6,7, dan 8 MST, berpengaruh sangat nyata pada umur tanaman 1 MST. Rata-rata tinggi tanaman pada masing-masing perlakuan disajikan dalam Tabel 2.

Tabel 1. Karakteristik bahan tanam dari berbagai perlakuan

\begin{tabular}{llll}
\hline \multirow{2}{*}{ Karakteristik } & \multicolumn{2}{c}{ Asal Daerah } \\
\cline { 2 - 4 } & Kangean & Bangkalan & Lumajang \\
\hline \multirow{2}{*}{ Batang } & Bentuk batang bulat & Bentuk batang lurus & Bentuk batang lurus \\
Warna & Warna coklatmuda & Warna coklat muda & Warna kecoklatan
\end{tabular}




\begin{tabular}{|c|c|c|c|}
\hline Diameter & Diameter batang lebar $5(\mathrm{~cm})$ & $\begin{array}{l}\text { Diameter batang kecil } 5,4 \\
(\mathrm{~cm})\end{array}$ & Diameter batang kecil 5,3 (cm) \\
\hline & Daunnya tidak terlalu tebal & Daunnya tebal & Daunnya tipis \\
\hline
\end{tabular}

Tabel. 2. Rata - rata tinggi tanaman $(\mathrm{cm})$ pada perlakuan beda asal tanaman

\begin{tabular}{lllllllllc}
\hline & \multicolumn{7}{c}{ Rata - rata tinggi tanaman pada umur (MST) } \\
\cline { 2 - 10 } Perlakuan asal tanaman & 1 & 2 & 3 & 4 & 5 & 6 & 7 & 8 \\
\hline A1: (Kangean) & $27,8 \mathrm{~b}$ & 19,4 & 22,4 & 27,9 & 27,8 & 26,8 & 27,5 & 32,2 \\
& 12,1 & & & & & & & \\
A2: (Bangkalan) & $\mathrm{ab}$ & 13,5 & 17,1 & 23,8 & 20,3 & 20,2 & 23,2 & 22,7 \\
A3: (Lumajang) & $11,6 \mathrm{a}$ & 15,6 & 20,1 & 24,7 & 23,7 & 20,8 & 25,6 & 26,8 \\
\hline BNJD 5\% & $* *$ & $\mathrm{~ns}$ & $\mathrm{~ns}$ & $\mathrm{~ns}$ & $\mathrm{~ns}$ & $\mathrm{~ns}$ & $\mathrm{Ns}$ & $\mathrm{ns}$ \\
\hline
\end{tabular}

Keterangan : Angka - angka yang didampingi oleh huruf yang sama padakolom yang sama tidak berbeda nyata pada UjiJarak Duncan 5\%, ns: non signifikan

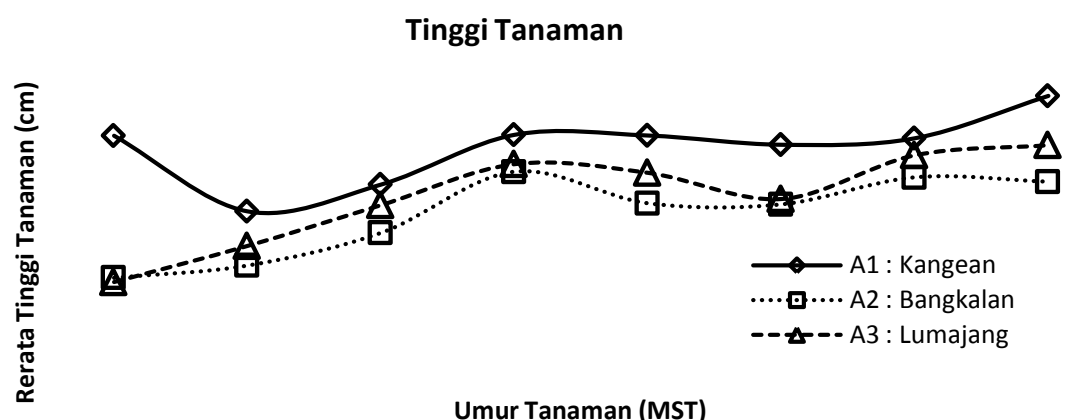

Gambara 2. Grafik rata - rata tinggi tanaman pada berbagai perlakuan

Pada Tabel. 2 terlihat umur tanaman 1 MST, perlakuan A1: Kangean memiliki tinggi tanaman tertinggi yaitu $27,8 \mathrm{~cm}$, terendah pada perlakuan A2: Lumajang (11,6 $\mathrm{cm})$ tetapi tidak berbeda nyata dengan perlakuan Bangkalan. Pada umur tanaman 2 sampai 8 MST tidak berpengaruh nyata pada berbagai perlakuan pada tinggi tanaman.

Secara umum tinggi tanaman pada setiap perlakuan selalu meningkat seiring dengan bertumbuhnya umur tanaman. Dari data tersebut menunjukkan bahwa perlakuan pada tinggi tanaman umur 1 MST berkisar antara 11,6 - 27,8 $\mathrm{cm}$, dan tinggi tanaman pada umur $2 \mathrm{MST}$, rata - rata tinggi tanaman mengalami penurunan $\pm 10 \mathrm{~cm}$, sehingga tinggi tanaman berumur 2 MST sebesar 13,5 - 19,4 cm. Sementara $4,5,6,7,8$, MST, secara berturut - turut rata - rata tinggi tanaman mengalami peningkatan $\pm 13 \mathrm{~cm}$. Tinggi tanaman pada umur 4 hingga 8 MST sebesar antara 23,8 - 32,2.

\section{Jumlah daun}

Hasil analisis sidik ragam jumlah daun menunjukkan bahwa asal tanaman berbeda daerah tidak memberikan pengaruh nyata terhadap jumlah daun pada semua umur pengamatan. Rata - rata jumlah daun pada masing - masing perlakuan disajikan dalam Tabel 3.

Tabel 3. Rata - rata jumlah daun (helai) pada perlakuan beda asal tanaman

\begin{tabular}{lrrrrrrrrr}
\hline & \multicolumn{7}{c}{ Rata - rata jumlah daun pada MST } \\
\cline { 2 - 9 } Perlakuan asal tanaman & 1 & 2 & 3 & 4 & 5 & 6 & 7 & 8 \\
\hline A1: (Kangean) & 30,6 & 70,4 & 112,0 & 161,0 & 139,8 & 121,8 & 127,4 & 316,0 \\
A2: (Bangkalan) & 17,6 & 31,2 & 58,0 & 82,6 & 101,2 & 94,8 & 193,0 & 195,6 \\
A3: (Lumajang) & 32,0 & 48,4 & 82,8 & 95,0 & 117,2 & 179,8 & 123,2 & 284,8 \\
\hline
\end{tabular}




\begin{tabular}{llllllllllllllll}
\hline BNJD 5\% & ns & ns & ns & Ns & Ns & ns & ns & ns \\
\hline
\end{tabular}

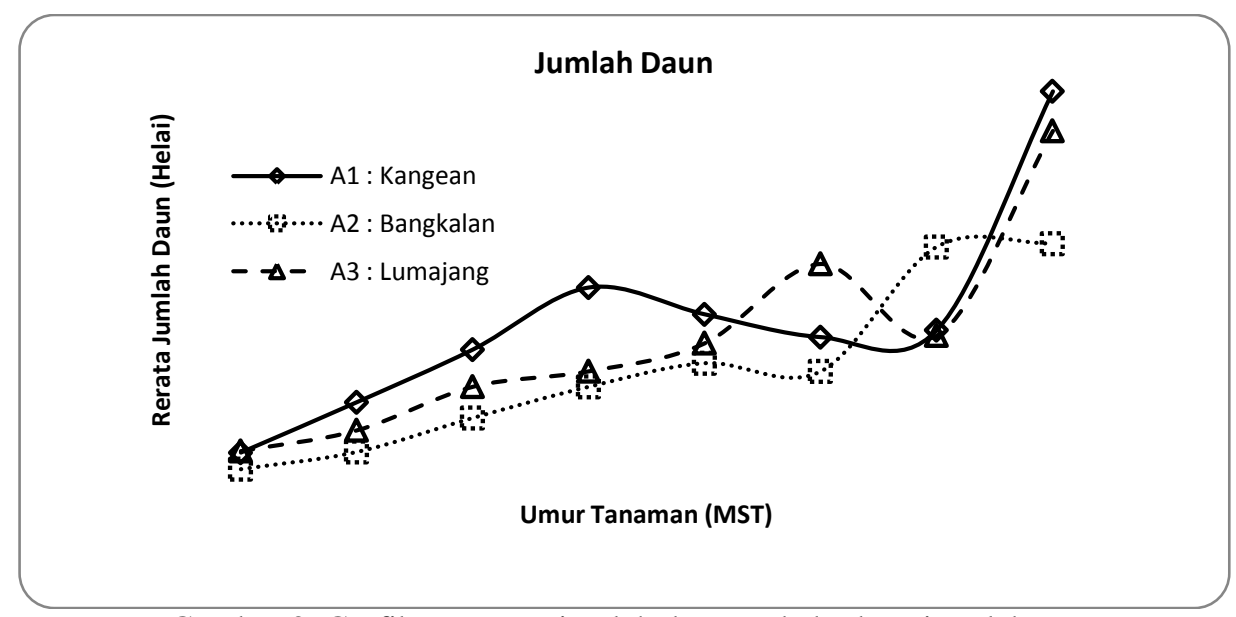

Gambar 3. Grafik rata- rata jumlah daun pada berbagai perlakuan

Pada Tabel 3.menunjukkan bahwa umur tanaman pada jumlah daun (helai) pada pengamatan pertama rata rata jumlah daun tertinggi pada perlakuan A3 : Lumajang yaitu 32,0. Sedangkan pada pengamatan kedua rata - rata jumlah daun tertinggi pada perlakuan A1 : Kangean yaitu 70, 4. Dan rata - rata jumlah daun pada pengamatan ketiga tertinggi pada perlakuan A1 : Kangean yaitu 112,0. Dan rata - rata jumlah daun pada pengamatan keempat tertinggi pada perlakuan A1 : Kangean yaitu 161,0. Sedangkan rata - rata jumlah daun pada pengamatan kelima tertinggi pada perlakuan A1 : Kangean yaitu 139,8. Dan rata - rata jumlah daun pada pengamatan keenam tertinggi pada perlakuan A3 : Lumajang yaitu 179,8 . Sedangkan rata - rata jumlah daun pada pengamatan ketujuh tertinggi pada perlakuan A2 : Bangkalan yaitu 193,0. Dan rata - rata jumlah daun pada pengamatan kedelapan kecenderungan tertinggi pada perlakuan A1 : Kangean yaitu 316,0.

Dari data tersebut pada jumlah daun menunjukkan pada setiap perlakuan selalu meningkat seiring dengan bertambahnya umur tanaman. Perlakuan A1 pada umur tanaman 1 hingga $8 \mathrm{MST}$, rata - rata jumlah daun secara berturut - turut mengalami peningkatan sebesar antara 30,6 - 316,0 cm, sementara pada perlakuan A2 dan A3 rata - rata jumlah daun mengalami penurunan sebesar 17,6 - 195,6 cm dan $32,0-284,8$.

\section{Jumlah cabang}

Hasil analisis sidik ragam jumlah cabang menunjukkan bahwa asal tanaman berbeda daerah tidak memberikan pengaruh nyata terhadap jumlah cabang pada semua umur tanaman. Rata - rata jumlah cabang pada masing - masing perlakuan disajikan dalam Tabel 4.
Pada Tabel 4 terlihat bahwa jumlah cabang (helai) pada pengamatan pertama rata - rata jumlah daun tertinggi pada perlakuan A3 : Lumajang yaitu 4,0. Sedangkan pada pengamatan kedua rata - rata jumlah daun tertinggi pada perlakuan A1 : Kangean yaitu 4,8. Dan rata - rata jumlah daun pada pengamatan ketiga tertinggi pada perlakuan A3 : Lumajang yaitu 6,4. Dan rata - rata jumlah daun pada pengamatan keempat tertinggi pada perlakuan A1 : Kangean yaitu 8,2. Sedangkan rata - rata jumlah daun pada pengamatan kelima tertinggi pada perlakuan A1 : Kangean yaitu 24,0. Dan rata - rata jumlah daun pada pengamatan keenam tertinggi pada perlakuan A3 : Lumajang yaitu 20,8. Sedangkan rata - rata jumlah daun pada pengamatan ketujuh tertinggi pada perlakuan A1 : Kangean yaitu 21,2. Dan ratarata jumlah daun pada pengamatan kedelapan kecenderungan tertinggi pada perlakuan A3 : Lumajang yaitu 27,4 .

Secara umum pertumbuhan jumlah cabang pada setiap perlakuan selalu meningkat seiring dengan bertumbuhnya umur tanaman. Jumlah cabang pada umur tanaman 1 hingga 4 MST, secara berturut - turut mengalami penurunan sebesar $\pm 5 \mathrm{~cm}$ sehingga rata - rata jumlah cabang sebesar 2,4-8,2 cm, sementara pada jumlah cabang umur 5 hingga 8 MST, rata - rata jumlah cabang mengalami peningkatan yang cukup banyak sebesar $\pm 13 \mathrm{~cm}$, sehingga jumlah cabang umur 5 hingga 8 MST berkisar 21,8 - 26,2.

\section{Bobot basah tanaman (g)}

Hasil analisis sidik ragam bobot basah tanaman menunjukkan bahwa asal tanaman beberapa daerah yang 
berbeda tidak berpengaruh nyata terhadap bobot basah tanaman.

Pada Tabel 5 bobot basah tanaman pada daun, A1 cenderung mempunyai bobot tertinggi dibandingkan perlakuan A2 dan A3. Bobot basah batang A3 cenderung mempunyai bobot tertinggi dibandingkan perlakuan A1 dan A2. Sedangkan Bobot basah umbi A1 cenderung mempunyai bobot tertinggi dibandingkan perlakuan A2 dan A3.

Tabel4. Rata - rata jumlah cabang (helai) pada perlakuan beda asal tanaman

\begin{tabular}{lcccccccc}
\hline \multicolumn{1}{c}{$\begin{array}{c}\text { Perlakuan } \\
\text { asal tanaman }\end{array}$} & \multicolumn{7}{c}{ Rata - rata jumlah cabang pada umur } & MST \\
\cline { 2 - 9 } & 1 & 2 & 3 & 4 & 5 & 6 & 7 & 8 \\
\hline A1: (Kangean) & 3,6 & 4,8 & 5,4 & 8,2 & 24,0 & 16,4 & 21,2 & 26,2 \\
A2: (Bangkalan) & 2,4 & 3,0 & 3,6 & 4,4 & 19,6 & 15,2 & 16,6 & 19,0 \\
A3: (Lumajang) & 4,0 & 4,2 & 6,4 & 5,6 & 21,8 & 20,8 & 17,4 & 27,4 \\
\hline \multicolumn{1}{c}{ BNJD 5\% } & ns & ns & ns & ns & Ns & ns & ns & ns
\end{tabular}

Keterangan : ns: non signifikan.

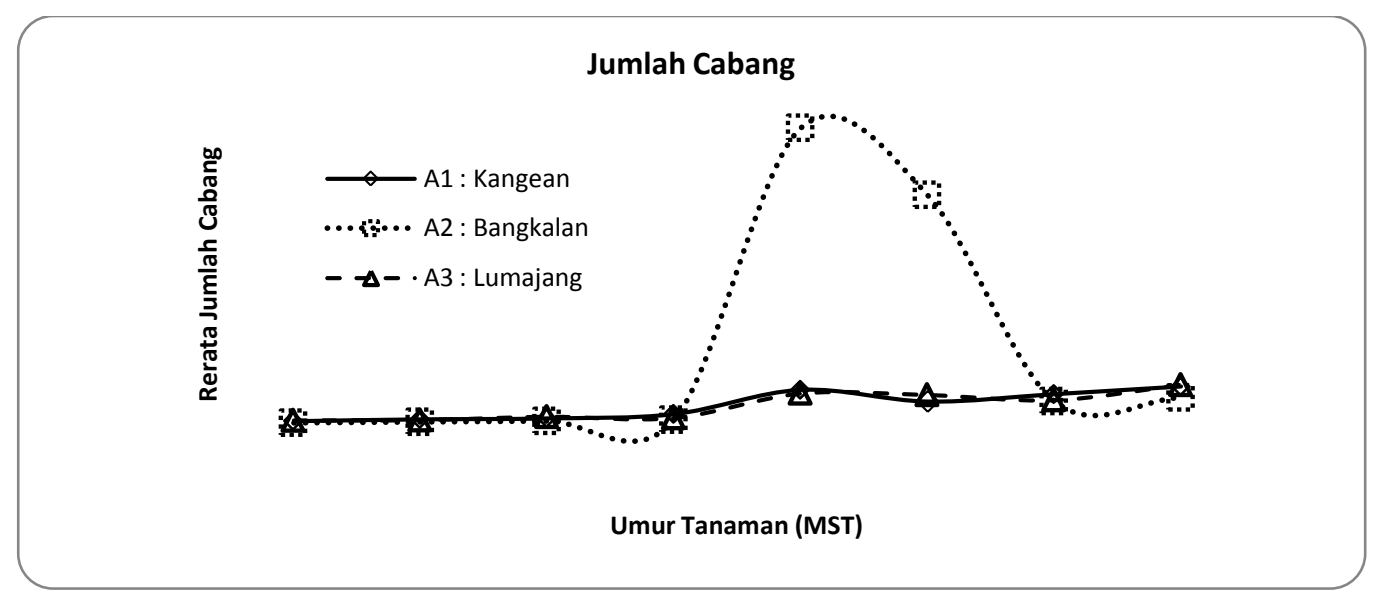

Gambara 4. Grafik rata- rata jumlah cabang pada berbagai perlakuan

Tabel 5. Rata - rata bobot basah tanaman $(\mathrm{g})$ pada perlakuan beda asal tanaman

\begin{tabular}{lccc}
\hline \multirow{2}{*}{ Perlakuan asal tanaman } & \multicolumn{3}{c}{ Bobot basah tanaman pada } \\
\cline { 2 - 4 } & Daun & Batang & Umbi \\
\hline A1:(Kangean) & 80,7 & 15,6 & 9,4 \\
A2:(Bangkalan) & 67,3 & 14,7 & 4,9 \\
A3:(Lumajang) & 75,9 & 29,1 & 8,5 \\
\hline BNJD 5\% & $\mathrm{ns}$ & $\mathrm{Ns}$ & $\mathrm{ns}$ \\
\hline
\end{tabular}

Keterangan : ns: non signifikan. 


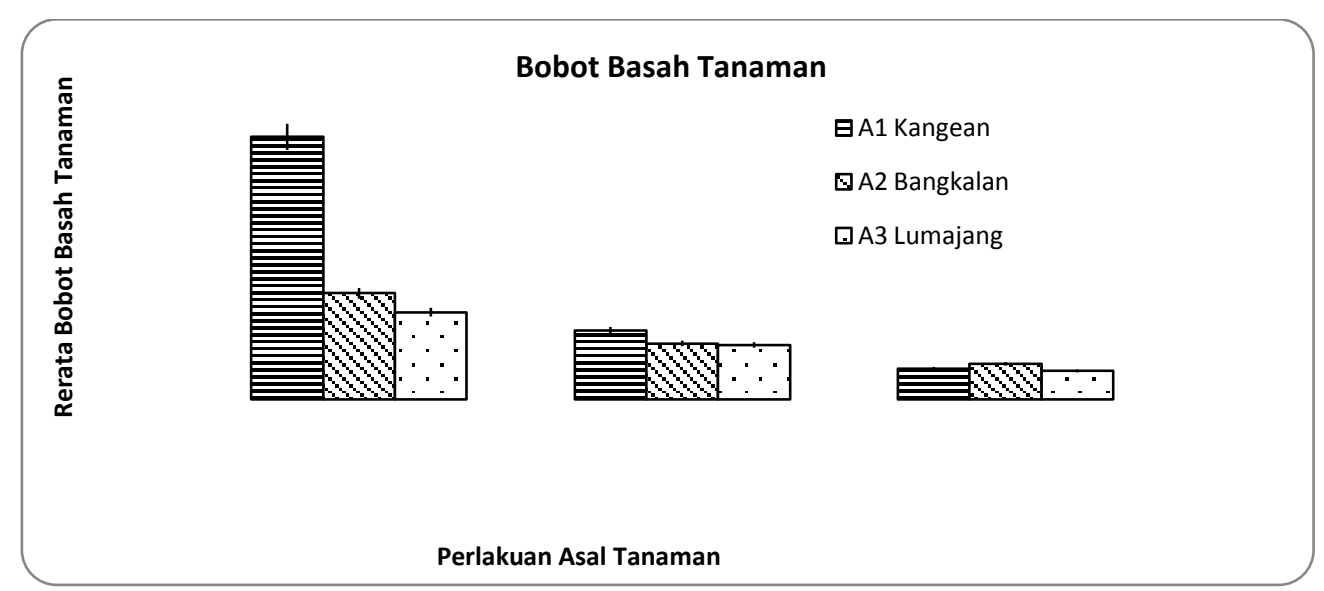

Gambar 5. Diagram batang rata - rata bobot basah pada berbagai perlakuan

Tabel. 6. Rata - rata bobot kering tanaman $(\mathrm{g})$ pada perlakuan beda asal tanaman

\begin{tabular}{lccc}
\hline \multirow{2}{*}{ Perlakuan asal tanaman } & \multicolumn{3}{c}{ Bobot kering tanaman pada } \\
\cline { 2 - 4 } A1: (Kangean) & Daun & Batang & Umbi \\
A2: (Bangkalan) & 24 & 6,2 & 2,8 \\
A3: (Lumajang) & 9,5 & 5,0 & 3,2 \\
BNJD 5\% & 7,8 & 4,9 & 2,6 \\
\hline
\end{tabular}

Keterangan : ns: non signifikan

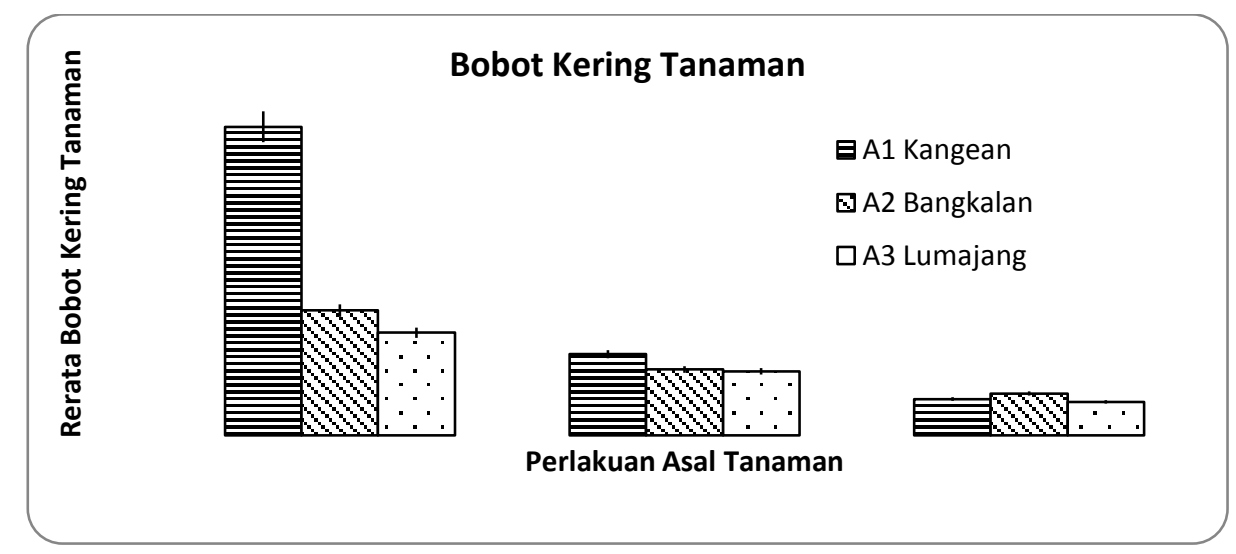

Gambar 6. Diagram batang rata - rata bobot kering pada berbagai perlakuaKandungan alkaloid dan steroid.

Tabel 7 Rata - rata kandungan alkaloid, teroid pada perlakuan asal tanaman

\begin{tabular}{lcccccc}
\hline \multirow{2}{*}{ Perlakuan Asal Tanaman } & \multicolumn{2}{c}{ Kandungan Alkaloid } & & & \multicolumn{2}{c}{ Kandungan Steroid } \\
\cline { 2 - 3 } \cline { 5 - 7 } & Daun & Umbi & & & Daun & Umbi \\
\hline A1: (Kangean) & $3,88 \mathrm{a}$ & $1,98 \mathrm{a}$ & $\mathrm{s}$ & & $1,93 \mathrm{a}$ & $1,99 \mathrm{a}$ \\
A2: (Bangkalan) & $4,90 \mathrm{~b}$ & $2,77 \mathrm{~b}$ & & $2,53 \mathrm{~b}$ & $2,21 \mathrm{~b}$ & $2,35 \mathrm{~b}$ \\
A3: (Lumajang) & $5,15 \mathrm{c}$ & $2,88 \mathrm{~b}$ & & $3,09 \mathrm{c}$ & $* *$ \\
\hline BNJD 5\% & $* *$ & $* *$ & & $* *$ & \\
\hline
\end{tabular}

Keterangan : Angka - angka yang sama didampingi oleh huruf yang sama pada kolom yang sama berbeda nyata pada uji Duncan 5\%. 
Pada Tabel 7terlihat bahwa kandungan alkaloid dan steroid baik pada umbi, tertinggi adalah A3 : Lumajang, tapi secara statistik tidak berbeda dengan A2 : Bangkalan dan terendah A1 : Kangean. Sedangkan pada daun tertinggi A3 : Lumajang dan terendah A1 : Kangean.

\section{Pembahasan}

Tanaman kolesom yang dibudidayakan dari ketiga daerah meliputi: Kepulauan Kangean, Kabupaten Bangkalan, dan Kabupaten Lumajang. Asal bibit tanaman kolesom yang digunakan dari ketiga daerah tersebut tidak dibudidayakan, Tanaman kolesom banyak dijumpai tumbuh secara liar di ketiga daerah tersebut. Kangean tergolong daerah panas, ketinggian tempat kira-kira 20-30 m dpl, dengan jenis tanah tergolong grumosol. Kondisi lingkungan dibangkalan tergolong dataran rendah dan panas ,dengan ketinggian tempat 40-50 m dpl,tanah latosol. Lumajang Ketinggian daerah bervariasi dari $0 \mathrm{~m}-3.676 \mathrm{~m}$ dpl (dari permukaan laut) dan yang terluas berada pada ketinggian 100-500mdpl yaitu seluas 63.405,50 hektar $(35,40 \%)$ dan yang tersempit berada pada ketinggian 0 - 25mdpl yaitu seluas 19.722,45 hektar $(11,01)$.

Hasil analisis sidikragam yang telah dilakukan padatinggi tanaman menunjukkan bahwa perlakuan asal tanaman berpengaruh sangat nyata pada umur tanaman1 MST. Perlakuan Kangean memiliki tinggi tanaman tertinggi yaitu $27,8 \mathrm{~cm}$, terendah pada perlakuan Lumajang $(11,6 \mathrm{~cm})$ tetapi tidak berbeda nyata dengan perlakuan Bangkalan. Pada umur tanaman 2 sampai 8 MST tidak berpengaruh nyata pada berbagai perlakuan pada tinggi tanaman.Hal ini disebabkan oleh adanya perbedaan fase pertumbuhan. Kolesom asal tanaman berbeda daerah diduga masih berada pada fase transisi antara juvenil menuju dewasa. Pemotongan stek dari batang akan memicu bekerjanya meristem ujung yang menghasilkan sel-sel baru di ujung akar atau batang yang mengakibatkan tanaman bertambah tinggi atau panjang (Hartmann et al., 1990).

Hasil analisis sidikragam yang telah dilakukan pada jumlah daun pada perlakuan asal tanaman memberikan pengaruh nyata pada semua umur pengamatan. Menunjukkan bahwa nilai rata - rata tertinggi terdapat pada perlakuan Asal Kangean yaitu 316,0 pada pengamatan minggu ke 8 , dan nilai terendah terdapat pada perlakuan Asal Bangkalan yaitu 17,6 pada pengamatan minggu ke 1 . Sesuai dengan pernyataan Tjitrosoepomo (1999), semakin meningkatnya jumlah cabang maka semakin meningkat pula jumlah daun pada tanaman kolesom, sehingga jumlah daun asal tanaman akan muncul seiring dengan banyaknya cabang yang muncul.Pertumbuhan vegetatif kolesom, khususnya pertumbuhan jumlah daun mencapai puncaknya pada umur 8 MST (8minggu setelah tanam) kemudian menurun. Hasil penelitian ini berbeda dengan penelitian Udoh dan Akpan (2007) yang menyatakan kolesom mencapai masa dewasa atau puncak pertumbuhan vegetatif sekitar 5-6 minggu setelah tanam.

Hasil analisis sidikragam yang telah dilakukan pada jumlah cabang pada perlakuan asal tanaman berbeda daerah tidak memberikan pengaruh yang nyata. Menunjukkan bahwa nilai rata - rata yang tertinggi terdapat pada perlakuan Asal Bangkalan yaitu 27,4 pada pengamatan minggu ke 8 , dan nilai terendah pada perlakuan Asal Bangkalan yaitu 2,4 pada pengamatan minggu ke 1. Hal ini diduga disebabkan terkait faktor interaksi antara keadaaninternal tanaman dengan lingkungan tumbuh. Faktorinternal yang berperan dalam hal ini adalah fasepertumbuhan sehingga pertumbuhan jumlah cabang tidak stabil. Tanaman muda yang masih giat melakukan pertumbuhan lateral, sedangkan stek melakukan pertumbuhan apika (Hartmann et al., 1990).

Hasil analisis sidikragam yang telah dilakukan pada bobot basah tanaman dan bobot kering tanaman pada perlakuan asal tanaman berbeda daerah tidak memberikan pengaruh yang nyata. Menunjukkan bahwa nilai rata - rata pada bobot basah tanaman yang tertinggi terdapat pada perlakuan Asal Kangean yaitu 80, 7 dan nilai terendah pada perlakuan Asal Bangkalan yaitu 4,9.Sedangkan pada bobot kering tanaman menunjukkan bahwa nilai rata - rata yang tertinggi terdapat pada perlakuan Asal Kangean yaitu 24 dan nilai yang terendah terdapat pada perlakuan Asal Lumajang yaitu 2,6. Hal initerdapat pada intraksi perlakuan. Bobot basah dan bobot keringtanaman kolesom ini ditentukan oleh adanya pemupukan, terutama kandungan N. Tresnawati (1999) menyatakan bahwa peningkatan pupuk nitrogen mengakibatkan penimbunan nitrat dalam tanaman yang mendorong pertumbuhan tanaman.

MenurutSugiarto (2006) bagian pucuk pada tanaman kolesom dapat dilakukan berkali-kali selama masahi dupnya. Pemanenan terbaik dilakukan setiap 3 minggu sekali yang memberikan produksi optimum. Pemanenan kolesomdengan tujuan untuk memperoleh daun segar dapat dilakukan dengan dua cara, yaitu pangkas pucuk dan cabutan. Dimana pangkas pucuk dilakukan dengan cara membuang tunas apical untuk mendorong tanaman agar bercabang banyak dan menghasilkan tunas baru. Sedangkan panen cabutan merupakan cara panen kolesom dengan cara dicabut beserta akarnya. Tanaman kolesom berasal dari berbeda daerah diantaranya kepulauan Kangean, Kabupaten Bangkalan dan KabupatenLumajang.

Dari hasil analisis kandungan alkaloid dan steroid pada daun dan umbi menunjukkan bahwa kandungan yang baik dan tertinggi terdapat pada perlakuan dari Kabupaten Lumajang. Terkait dengan hasil penelitian, kendala yang dihadapi pada uji alkaloid dan steroid adalah banyak tanaman yang pertumbuhannya kurang baik sehingga pada saat analisis hasil uji tersebut kurang maksimal. Sebagian besar terjadi pada tanaman kolesom yang berasal dari Kepulauan Kangean.

Metabolit sekunder merupakan senyawa metabolit yang tidak esensial bagi pertumbuhan organisme dan ditemukan dalam bentuk yang unik atau berbeda-beda antara spesies yang satu dan lainnya. Metabolit sekunder adalah berbagai macam reaksi yang produknya tidak secara langsung terlibat dalam pertumbuhan normal. Dalam hal ini metabolit sekunder berbeda dengan bahan metabolit intermediet yang memang merupakan produk dari 
metabolisme normal.Setiap organisme biasanya menghasilkan senyawa metabolit sekunder yang berbedabeda, bahkan satu jenis senyawa metabolit sekunder hanya ditemukan pada satu spesies dalam suatu kingdom. Penelitian tentang metabolisme sekunder sekarang ini semakin meningkat pesat, salah satu aspek yang semakin berkembang adalah pendekatan proses produksi metabolisme sekunder melalui kultur jaringan tanaman (Santoso, 2003).

Kandungan bahan bioaktif daun dan umbi tanaman kolesom yaitu diantaranya alkaloid, steroid, saponin, dan tanin. Alkaloid merupakan suatu golongan senyawa organik yang terbanyak ditemukan di alam. Hampir seluruh alkaloid berasal dari tumbuh-tumbuhan dan tersebar luas dalam berbagai jenis tumbuhan tingkat tinggi. Sebagian besar alkaloid terdapat pada tumbuhan dikotil sedangkan untuk tumbuhan monokotil dan pteridofita mengandunganosterong alkaloid dengan kadar yang sedikit.Sedangkan steroid merupakan senyawa yang memiliki kerangka dasar triterpena asiklik. Ciri umum steroid ialah sistem empat cincin yang tergabung. Cincin $\mathrm{A}, \mathrm{B}$, dan $\mathrm{C}$ beranggotakan enam atom karbon dan cincin $\mathrm{D}$ beranggotakan lima. Steroid mempunyai jenis jenis diantaranya pada tumbuhan (Sikroaltinol), pada hewan (Lanosterol), pada manusia Kolesterol (Wijayakusuma, H., 1996).

Hasil analisis ragam yang telah dilakukan pada kandungan alkaloid dan steroid yaitu pada daun dan umbi pada perlakuan asal tanaman berbeda daerah memberikan pengaruh yang sangat nyata. Menunjukkan bahwa nilai rata - rata pada kandungan alkaloid dan steroid yang tertinggi terdapat pada perlakuan Asal Lumajang yaitu 5,15 pada daun, dan nilai yang terendah terdapat pada perlakuan Asal Kangean yaitu 1,93 pada daun, sedangkan pada kandungan alkaloid dan steroid pada umbi yang tertinggi terdapat pada perlakuan Lumajang yaitu 2,88 dan terendah pada perlakuan Kangean yaitu 1,99 .

Faktor ketinggian tempat mempuyai hubungan yang erat dengan pola penggunaan tanah dan sangat menentukan kebebasan hidup tanaman serta besarnya penyebaran penduduk(DinasPertanianKabupatenLumajang). Perlakuan yang tertinggi pada perlakuan Lumajang, hal ini disebabkan karna faktor ekstral yaitu: suhu, kelembapan dan intensitas cahaya.

\section{KESIMPULAN}

Berdasarkan hasil penelitian dapat isimpulkan bahwa
Dari ketiga faktor perlakuan asal bibit tanaman A1: Kangean, A2: Bangkalan dan A3: Lumajang tidak berpengaruh nyata terhadap pertumbuhan dan hasil kecuali pada kandungan alkaloid dan steroid pada tanaman kolesom. Hasil yang tertinggi pada kandungan alkaloid dan steroid terdapat pada perlakuan asal bibit dari Kabupaten Lumajang.

\section{SARAN}

Perlu dilakukan penelitian lebih lanjut terkait perbedaan asal tanaman kolesomberbeda daerah yaitu: Kangean, Bangkalan, Lumajang terhadap pertumbuhan dan hasil serta kandungan alkaloid dan steroid.

\section{DAFTAR PUSTAKA}

Hartmann, T.H., D.E. Kester, F.T. Davies. 1990. PlantPropagation. 5th Ed. Prentice Hall. New Jersey.647 p.

Mualim L., S.A. Azis. M. Melati. 2009. Kajian pemupukan NPK dan jarak tanam pada produksi antosianin daun kolesom (Talinum triangulare (Jazq.)Willd). J. Agron. Indonesia 37 (1):55-61

Santoso, U., Nursandi., F 2003. Metabolisme Sekunder Melalui Kultur Jaringan Tanaman, Edisi I, UMM, Malang.

SusantiH., S.A. Aziz, M. Melati. 2008. Produksi biomassa dan bahan bioaktif kolesom (Talinum triangulare (Jazq.)Willd) dari berbagai asal bibit dan dosis pupuk kandang ayam. Bul. Agron. 36:48-55.

Sugiarto N.T. 2006. Pengaruh umur dan frekuensi panen pada produksi pucuk kolesom (Talinumtriangulare Willd.). Skripsi. Departemen Budi Daya Pertanian. Faperta. IPB Bogor Udoh, E.J., S.B. Akpan. 2007. Measuring Technical efficiency of water leaf (talinum triangulare) production in Akwa Ibon State, Nigeria. American-Eurasian J. Agric. Environ. Sci. 2:518- 522 .

Tresnawati, E. 1999. Pengaruh pemberian pupuk nitrogen dan tingkat populasi terhadap pertumbuhan dan produksi radiks kolesom (Talinum paniculatum Gaertn.). Warta Tumbuhan Obat Indonesia 5(4):7-8.

Tjitrosoepomo, G. 1999. Morfologi Tumbuhan. Gadjah Mada University Press. Yogyakarta. 266 hal.

Wijayakusuma, H, 1996. Tanaman Berkhasiat Obat Indonesia. Jillid Ke-4 Pustaka Kartini. Jakarta.. 